\title{
Social Media in the Pandemic Era: Twitter User Sentiment Analysis Against COVID-19
}

\author{
Fajar Rahmanto $^{1^{*}}$, Muchamad Zaenuri ${ }^{2}$
}

\author{
${ }^{1,2}$ Department of Government Affairs and Administration, Universitas Muhammadiyah Yogyakarta, Indonesia \\ Corresponding author. E-mail: fajarrahmantol@gmail.com
}

\begin{abstract}
Social media has become the choice to access various information related to disasters. This article aims to determine the level of public responsiveness to the COVID-19 pandemic disaster through social media Twitter. This research used descriptive qualitative with a literature study approach. Information was collected from Twitter using N-Capture regarding the COVID-19 pandemic in March 2020. The data analysis techniques were done using the NVivo12 Plus software with a query analysis approach. The results showed the community's responsiveness to the COVID-19 pandemic disaster since the advent of the COVID-19 outbreak in Indonesia in early March was enlivened with hashtags (\#lawancovid19) of 14,930 counts. Through hashtag \#lawancovid19, the bnpb-Indonesia account with $(35.24 \%)$ and the ministry of health ministry account (20. 68\%) are the two Twitter accounts used most in March. The \#lawancovid19 narrative on Twitter developed by the government is a form of information and education communication (IEC) actions regarding the COVID-19 pandemic as part of a preventive effort to prevent the spread of an increasing outbreak. Thus, social media can be utilized by the government and the community to increase effectiveness and efficiency in disseminating disaster information.
\end{abstract}

Keywords: Social media; Disasters; pandemics; COVID-19

\section{INTRODUCTION}

Social media has become an option as a means or tool to access disaster-related information (Handayani et al., 2018). Combining government data sources and online information such as geoportals, online maps, and social media can minimize the potential for data shortages during the disaster emergency response (Yulfa et al., 2019). Support smart governance necessary to improve the quality of the substance of the publication of information that still prioritizes the validity of data and information and full support from stakeholders in realizing an open data portal that is comprehensive, representative, user friendly, and secure. (Maizunati, 2018). Thus, community preparedness and the readiness of disaster management agencies in using social media to share information need to be supported by known stakeholders to have information attractiveness that makes its use effective, targeted, and optimal (Barata et al., 2018).

The Covid-19 pandemic is a worldwide disease epidemic in Wuhan China, at the end of 2019 (Auliya, 2020). The spread of COVID-19 throughout the world is happening very quickly, with the number of cases infected with this virus mostly occurring in men aged $8-92$ years and the risk of death reaching between $2-2.3 \%$ (Lupia et al., 2020). The potential for 2019-nCoV to cause a pandemic impacts the soaring tax burden of the global economy of $\$ 30$ to $\$ 100$ billion. Thus, it is estimated that the world economic burden due to pressure from this virus is estimated to reach $1 \%-2 \%$ of GDP (Gross
Domestic Product), which for now is more than $20 \%$ of the world's GDP is now contributed by China(Arshad Ali et al., 2020).

The disaster management policies that have been implemented have not been optimal due to the lack of uneven socialization and the lack of infrastructure, and the number of human resources(Silmi et al., 2019). In addition, another obstacle in the use of social media is the lack of human resources capable of managing disaster information so that it is always updated (Subekti, Hafiar, \& Bakti, 2020). Efforts are needed to improve the capacity of human resources in disaster management with training and simulations to deal with sustainable disasters as well as strengthening coordination between stakeholders involved in disaster management (Farizi et al., 2016). Therefore, human resources in various types of public institutions need to improve their competence in e-resources management, managerial leadership, digital literacy, and research and carry out transformations in preparation for the increasingly rapid changes in creating a knowledge society. (Nashihuddin \& Suryono, 2018).

The response from community groups to disaster crisis communications delivered by disaster management agencies shows positive feedback (Juneza \& Puworini, 2016). HR support performance management is very necessary to increase the credibility of the institution or institution by making the apparatus resources competency-oriented towards 
ICT, which plays an important role in supporting the implementation of tasks in the future (Rustandi, 2019). However, to implement technology in the era of disruption, it is necessary to have government officials who have the competence, capacity, and integrity in their work while still prioritizing the humanization aspect in providing public services (Rusdan, 2019).

Many previous studies on the role of social media in disasters have been carried out. A study conducted by Yuliana (2019) found that analysis in social networks can be integrated for emergency management and emergency response plans at the national, regional, and local levels. (Yuliana, 2019). Then the study of Subekti et al. (2020) shows that the role of social media can create new patterns of communication and social participation between government, private, and community organizations that have been used as information media that are easily accessible to the public (Subekti et al., 2020). Research conducted by Fahriyani et al. (2020) revealed the social media Twitter used by the National Disaster Management Agency (BNPB) to disseminate information related to disasters starting from the pre-disaster, emergency response post-disaster stages (Fahriyani et al., 2020).

Looking at the negative impacts caused by the spread of the COVID-19 pandemic outbreak for the global community and based on previous research regarding the use of social media in disasters in the era of disruption, the author has not found a review on how the sentiments of the Twitter user community towards the covid-19 pandemic. This paper aims to determine the level of community responsiveness to the pandemic disaster that occurred through Twitter social media. The source of the study in this paper is various information about the COVID-19 pandemic disaster on Twitter. The development of increasingly sophisticated communication technology can encourage an excellent public response to the outbreak of the COVID-19 pandemic and increase community disaster mitigation knowledge. So that,

\section{METHODOLOGY}

This article uses a descriptive qualitative research method with a literature study approach to obtain research data and information. Qualitative descriptive is research conducted to provide in-depth descriptions of qualitative research (Bandur, 2019). The literature study approach is defined as a way to obtain research information from books, the internet, and previous research that is closely related to the object of research(Farida, 2019). The researcher uses qualitative research methods because it relates to the focus of the research, namely to find out about the level of community responsiveness to the occurrence of the COVID-19 pandemic through Twitter. The information collected comes from Twitter using N-Capture, a tool that can automatically retrieve various information data regarding the COVID-19 pandemic. Research information from Twitter was taken for one month, namely in March 2020, because in that month COVID-19 began to cause many deaths, it became public attention for social media users, especially Twitter. The data analysis technique in this study is a query approach using the NVivo12 Plus application (Bandur, 2019). Meanwhile, for the presentation of data in general, qualitative research is carried out using matrices, graphs, charts, and narrative texts, which are then drawn to conclusions with meaning through the reflection of research information data.

\section{RESULTS AND DISCUSSION}

COVID-19 was declared by the World Health Organization (World Health Organization) as a pandemic in most countries worldwide, including Indonesia. This makes public health authorities continue to monitor the situation and conditions that occur as a preventive measure by learning about COVID-19 to build a response to this new virus and its related outbreaks (Lai et al., 2020). The lack of knowledge about COVID-19 has made all countries raise high vigilance to reduce the risk due to this outbreak. Given the high knowledge gap regarding the handling of COVID-19, encouraging the entire world health community to jointly contribute to building and preparing a database on COVID19 starting at the local, regional, and international levels.(Ling et al., 2020).

Disaster events can occur at any time, suddenly and with unpredictable human capabilities. Disasters in each region cannot be eliminated, but with well-managed disaster management, the potential for disaster risk can be minimized. Areas with a high level of disaster potential certainly make the area have a high level of vulnerability to the risk of a disaster. Disasters that are not managed properly will pose a serious threat to the survival of the wider community. Indonesia is one of the countries with a high potential for disaster vulnerability, both natural disasters and disasters caused by humans (Faradilla, 2018). In general, disasters are categorized into two; natural and non-natural disasters. The risk of non-natural disasters is higher when compared to disasters caused by natural factors (Masdalina Pane et al., 2018). By letterKepmen No.17/kep/Menko/Kesra/x/95 disaster is a series of events caused by nature, humans, and or both that result in victims and human suffering, loss of property, damage to the environment, damage to infrastructure and public facilities, and cause disturbances to the order of life and community livelihoods. So that disaster mitigation is needed and active participation between the community and the government to build synergies and collaborate in disaster management efforts jointly. Community participation in disaster management can reduce disaster risk (Amalia \& Sari, 2018).

The era changes also affect the development of technology, which makes it easier for people to carry out various aspects of life. One form of technological development occurs with changes in media, ranging from written, print, electronic media to social media. This influences people's lives, especially with social media in the era of disruption. One of the social media widely used by the community is Twitter, where fellow users can interact and 
promote opinions to discuss the hottest issues that occur (trending topics) by participating through specific hashtags (Fahriyani et al., 2020).

\subsection{Social Media in the Disaster Sector}

In the era of digital technology, integrating technology in the disaster sector as an effort to mitigate through the dissemination of disaster data and information is a strategic effort of the government. This strongly supports transparency and disclosure of information to the public so that the public can easily access all information regarding disasters. Thus, in the era of digitalization, it has become an obligation for the government bureaucracy to make changes to adapt to environmental changes using fast and appropriate technology to fulfill public needs (Rusdan, 2019).

The urgency of the community regarding understanding how to manage disasters is very decisive in efforts to build disaster-aware community preparedness. To reduce the risk of disasters caused, it is necessary to disseminate information that is supported by the mobilization of information data dissemination quickly to the community and all stakeholders involved in disaster management. Knowledge of disasters in the form of information and first actions when a disaster occurs can be used as important information material immediately published to the wider community (Juneza \& Puworini, 2016).

Accelerating the mobilization of information in the field of disaster can be done by utilizing the power of social media. Social media is a site where anyone can create a personal web page that can be used to share various kinds of information and communicate. Social media was created to provide convenience in conducting interactive social interactions based on internet technology. This supports the democratization of information and knowledge, which impacts the behavior of netizens, which previously were primarily content consumptions to become content productions.

In handling the COVID-19 disaster as one of the national disasters faced by the Indonesian government, it is necessary to pay attention to the steps taken, including the communication pattern between stakeholders in implementing policies. The communication aspect is one of the essential parts in implementing any activity, including handling a disaster so that the disaster management carried out can run well, effectively, and efficiently. Good communication and coordination can build public trust and maintain public psychological stability so as not to be hit by panic, excessive anxiety, and fear (Silmi et al., 2019). It will provide easy access to information for the public and all parties involved in disaster mitigation activities for handling COVID-19.

\subsection{Responsiveness of Twitter Users to COVID-19 Through}

The development of social media has indirectly changed the pattern of interaction and communication in searching for information data. Entering the era of disruption or digital technology, social media has a critical position, especially in terms of disseminating various kinds of data and information. This is inseparable from the characteristics of social media itself which can penetrate time, affordability, and content and is more flexible (can be anytime and anywhere). The role of social media can create new patterns of communication and social participation between government, private and community organizations. It has been used as a medium of information that is easily accessible to the public.(Subekti et al., 2020).

One of the social media that is currently widely used to disseminate information related to disasters is Twitter. According to Mustafa (2013), Twitter is defined as a microblogging service which was officially introduced to the public in mid-2006. In the field of disasters, the use of Twitter as a medium for disseminating information about disasters has proven to be effective. This is shown from previous research conducted by Nee and Fusco (2015) stated that the dissemination of information in the form of tweets about disasters was posted more than broadcasting disaster news in journalistic media. For instance, the recent coronavirus (COVID-19) disaster became a global issue. It became a significant trend in various countries globally because it has been proven to harm all sectors of life, from health threats to chaos in the economic sector. COVID-19 is spreading rapidly worldwide ( Lupia et al., 2020), including in Indonesia, which has encouraged Twitter users from both the public and government organizations to respond quickly to this pandemic outbreak through various posts. This means that social media Twitter is a driving part of the community's social movement in participation and response to efforts for disaster management based on social motives (Mahaswari, 2012). The social motive in question is related to the COVID19 pandemic in moral support to the government to deal with this outbreak. The various kinds of information that many Twitter users respond to regarding content related to the COVID-19 disaster by Twitter users in Indonesia can be seen in the following image:

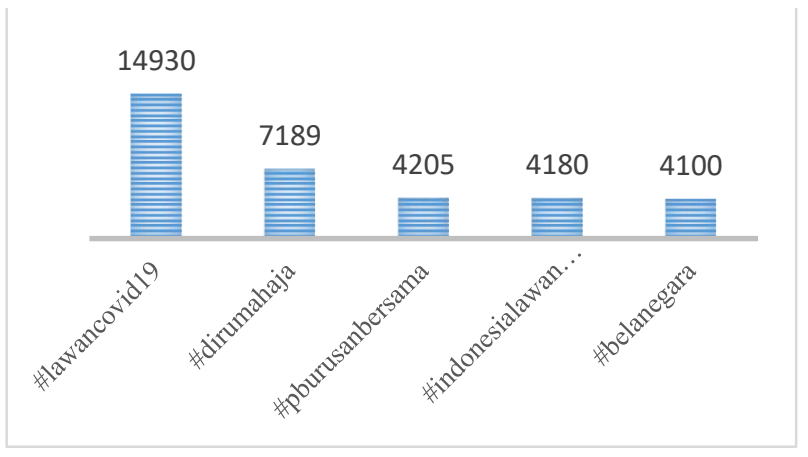

Figure 1. Public Responses of Twitter Users in Indonesia to the COVID-19 Disaster 
Based on Figure 1, it can be seen that since the emergence of the corona outbreak (COVID-19) in Indonesia in early March, the public's response through social media Twitter to the pandemic disaster was enlivened with the hashtag (\#lawancovid19) with a total of 14,930 counts. Then there is the hashtag (\#dirumahaja) with 7,189 counts, (\#pburusanbersama) with 4,205 counts, and the hashtag (\#indonesialawancovid19) with 4,180 counts, and the hashtag (\#belanegara) with 4,100 counts. According to Nasrullah (2015), through the use of Twitter, everyone can create a network of interactions with other users and disseminate information to discuss various issues that are currently being discussed (trending topics) using tweets and hashtags. The use of Twitter by government institutions in the field of disaster as a medium for disseminating information about disasters and for the public, Twitter is used to obtain information needs related to disasters (Fahriyani et al., 2020).
In the event of the COVID-19 occurred in Indonesia, disaster information provided via Twitter to the public related to the COIVI-19 pandemic includes procedures for handling the risk of COVID-19 transmission, urging the public to reduce outdoor activities to minimize the impact of the wider spread of the virus, displaying updated data on the development of COVID-19 cases nationally which includes the number of positive patients, recovered patients and the number of patients who died. Social media, such as Twitter, currently serves as a disseminator of information that government public agencies widely use. With a verified official account, information about anything can be found on social media.

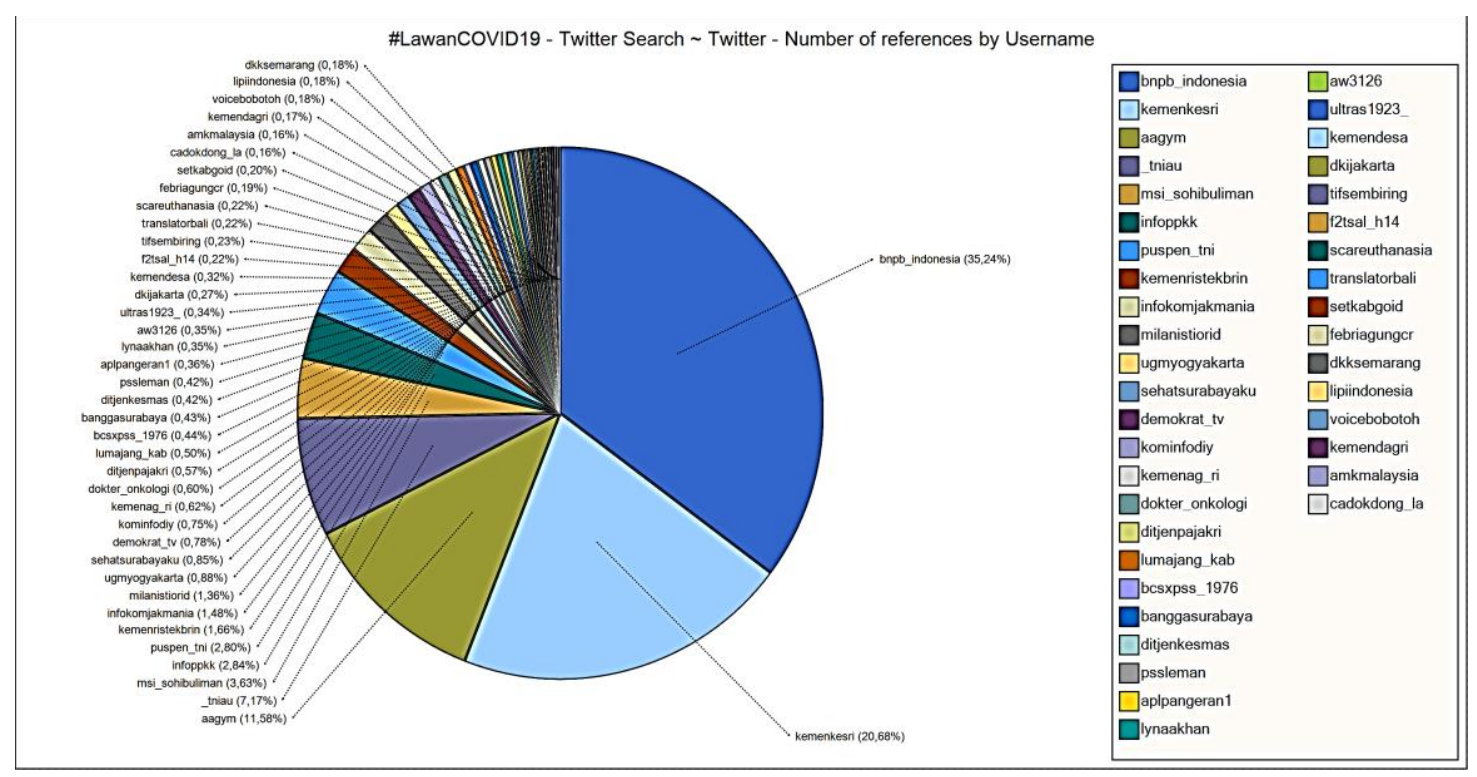

Figure 2. Auto Coding Results According to Twitter Users Against \#lawancovid19(Source: NVivo12 Plus Analysis, 2020)

Based on Figure 2, it can be seen that information in the form of socialization appeals via Twitter for the prevention of the COVID-19 pandemic is narrated in \#lawancovid19. The bnpb-Indonesia account (35.24\%) and the Ministry of Health account $(20.68 \%)$ were the two Twitter accounts that during March gave the most narratives about \#lawancovid19 because they are government institutions that have the main task and function to carry out disaster management and protect public health. The form of the narrative is in the form of socializing information on prevention, appeals to maintain cleanliness and health, appeals to wear masks and maintain distance, carry out social distancing and physical distancing to provide knowledge to the public about this pandemic outbreak. The high gap in knowledge regarding the handling of COVID-19 encourages the entire world health community to jointly contribute to building and preparing databases related to COVID-19(Ling et al., 2020).
The \#lawancovid19 narrative on Twitter which was built by the government as an effort to communicate information and education (KIE) regarding the COVID-19 pandemic, has also been responded to by other government agencies at the central level, such as in the accounts of the Ministry of Research and Technology, Ministry of Home Affairs, Ministry of Village, LipiIndonesia, Ministry of Home Affairs, and government agencies at the regional level such as lumajang_kab, kominfodiy, dkijakarta, etc. Interestingly, several football supporter community accounts on Twitter including infokomjakmania, milanistiorid, bcsxpss_1976, ultras1923 and voicebobotoh who also responded to the narration even though it was below $1 \%$ but it illustrates a high level of concern and social sense to assist the government in disseminating information about COVID-19 as part of preventive efforts to prevent the spread of an increasingly widespread pandemic outbreak. The use of social media is useful as a tool to encourage social movements from the community in their participation in disaster management so 
that it influences changes in the way institutions and societies plan and respond to disasters (Mahaswari, 2012; Yuliana, 2019). Disaster stakeholders need to support community preparedness and readiness of disaster management institutions in the use of social media to share information so that their use can be effective, targeted, and optimal. (Barata et al., 2018). Disaster management can be carried out optimally by increasing socialization, coordination, and communication supported by the competence of human resources in disaster management(Ariyanto, 2018; Silmi et al., 2019).

The role of social media is as a tool to build the government's narrative amid a crisis situation due to COVID19 through disaster management policies that have been determined to control the unstable public situation due to the COVID-19 disaster. In the disaster management stage, the narrative created by the government as part of building a positive image to the public that the country is ready and able to handle the crisis due to the COVID-19 pandemic that occurred in the territory of Indonesia. The main narrative in the delivery of communication by the Central Government and the local level to the community was with the hashtag (\#LAWANCOVID19) (Yulfa et al., 2019).

To accelerate the mobilization of information and communication regarding the handling of the COVID-19 disaster can be done by utilizing the role of social media. With various advantages, social media is an effective means of promotion or outreach to accelerate the dissemination of any information, including about disasters, because it can be accessed by anyone to have affordable information to the broader community (Handayani et al., 2018). This is inseparable from the characteristics of social media itself, which can penetrate time, has affordability, and more flexible content that can be accessed anytime and anywhere by the public. The role of social media that is able to create new patterns of communication and social participation between government, private and community organizations has been used as a medium of information that is easily accessible by the public (Subekti et al., 2020).

The increasingly widespread spread of COVID-19 has threatened various aspects of social life, economy, and public welfare. The role of the government as policymakers to deal with crisis situations due to the COVID-19 pandemic must be carried out carefully and precisely so as to create a calm society and understand what they must do for the surrounding environment. In this case, a clear understanding of strategic steps is needed in preventing the potential risk of spreading the COVID-19 pandemic by all parties, including the community. The effectiveness of disaster management can be done by improving coordination and communication (Ariyanto, 2018). Strengthening communication through government narratives in disaster management needs to be strengthened with other interrelated narratives so that they have an appeal to be used optimally to strengthen the public perception that the state is present and responsive to controlling crises due to the pandemic disaster.

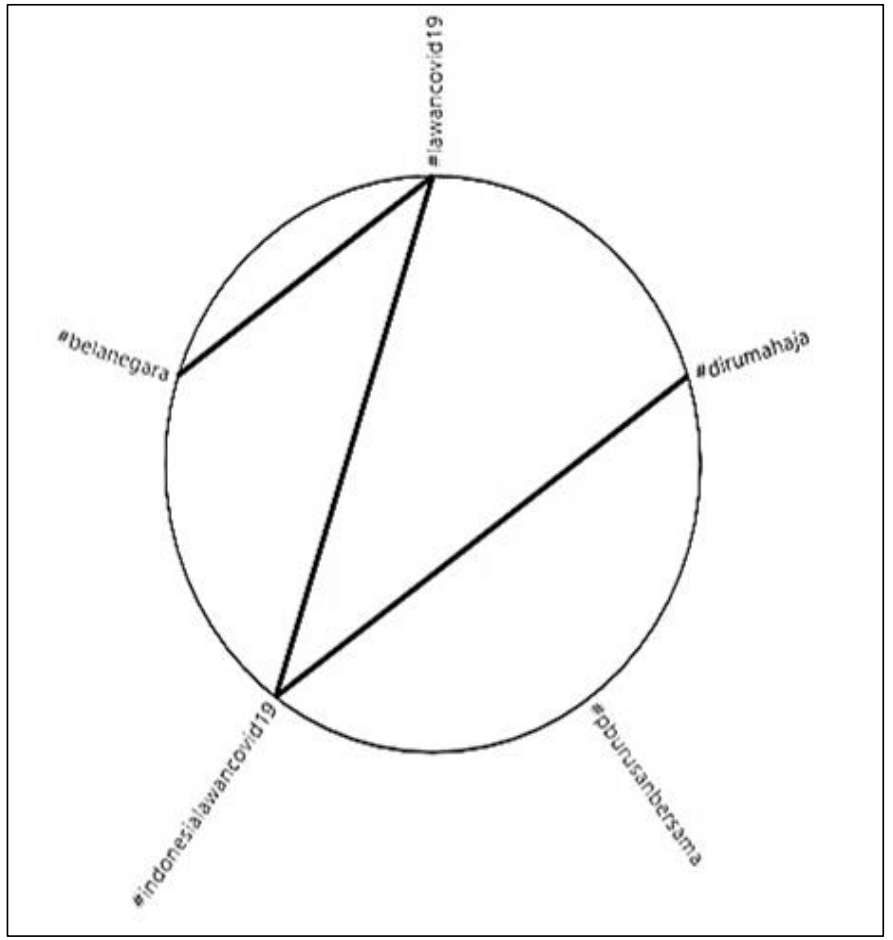

Figure 3. Coding Query Results Related to Narrative Content \#lawancovid19

Figure 3 shows various other narratives that were built apart from the hashtag opponentcovid19 by Twitter users for their response to the pandemic disaster, namely through \#belanegara, \#indonesialawancovid19 and \#dirumahaja. Hashtags can provide facilities for Twitter users to socialize and respond to events of significant concern at a certain time, such as the COVID-19 disaster. The advantages of social media, which are designed to facilitate communication, are interactive social interactions based on ICT. So, in the era of disruption, it is an obligation for the government bureaucracy to make changes by using fast and appropriate technology through the role of social media has chosen as a means to access disaster-related information (Handayani et al., 2018; Rusdan, 2019). The advantages of Twitter as a product of the development of social media make it an effective socialization tool for disaster education because anyone can access it. The dissemination network of information about disasters becomes more widely distributed.(Fahriyani et al., 2020). 


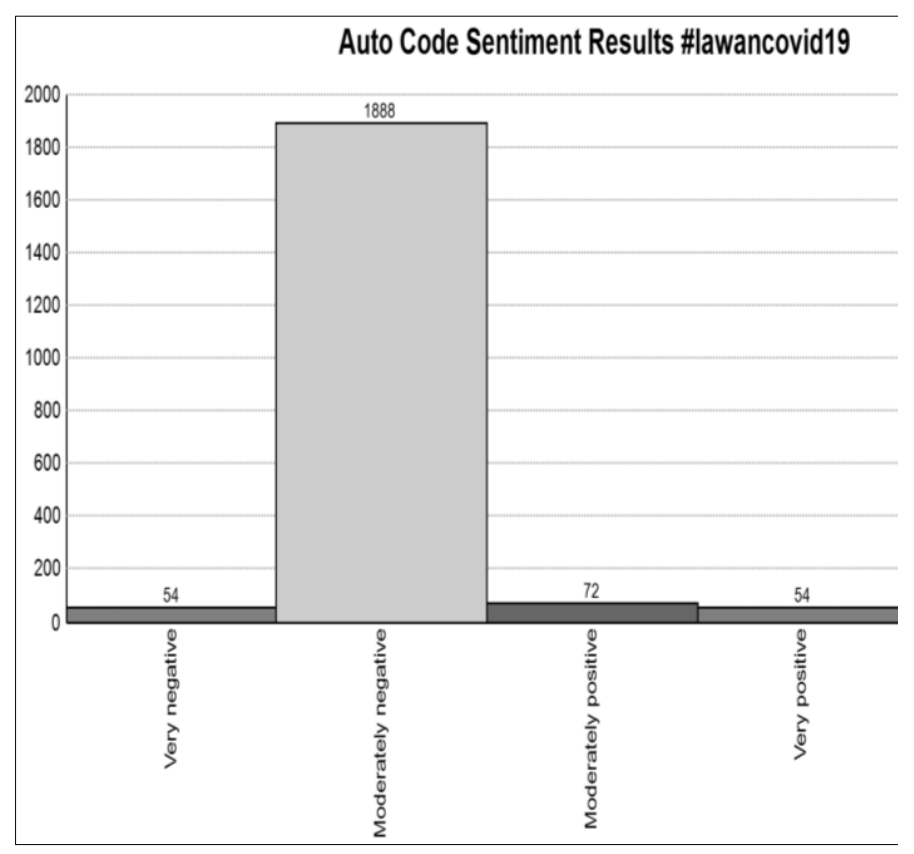

Figure 4. Results of Sentiment Analysis Against \#lawancovid19

Figure 4 shows the level of Twitter users' sentiment towards the hashtag \#lawancovid19, which is the government's main narrative in controlling COVID-19 disaster information on social media. The sentiment level for the hashtag \#lawancovid19 is 2,068 counts with a distribution of 1,888 counts of negative sentiment, 72 counts of positive sentiment, and 54 counts for positive and negative sentiments. Negative message content is in the form of an invitation to the public to reduce activities outside the home, avoid direct physical contact (physical distancing), reduce traveling long distances either by private vehicle or other public transportation. Twitter has social interaction effects in exchanging messages, sharing interests, and providing new ideas (Nurhadi, 2017). So, community response to disaster crisis communication delivered by disaster management agencies shows good feedback (Juneza \& Puworini, 2016).

The utilization of Twitter with hashtags facilities as part of narrative formation by the government benefits from disseminating disaster information. On the other hand, people in the era of disruption use Twitter to meet the need for information on the development of disasters such as the current COVID-19 pandemic. Social media has been used massively because it can interact and communicate without requiring physical preparation or showing personality attributes openly (War-wind \& Zainal, 2018). Of course, Twitter users who are active in following developments on information regarding the COVID-19 disaster will positively influence the disseminated information or news. Those who were previously unaware and even not educated on matters related to the COVID-19 pandemic became aware even though it has not gradually turned into actions that can be done in daily activities. Disaster information disseminated through Twitter is technically more effective and efficient because it does not requires large capital and follows the times. Development of disaster resilience is an effort to prepare for disasters where the speed in mobilizing disaster information by utilizing the resources and potential of social media is influenced by the level of adaptation to change. (Yuliana, 2019).

\section{CONCLUSION}

The level of community responsiveness to the COVID-19 pandemic disaster through social media Twitter is very high. It is known that since the emergence of the COVID-19 outbreak in Indonesia in early March, the hashtag (\#lawancovid19) has 14,930 counts. With a narrative built to provide information about the COVID-19 pandemic through the hashtag \#lawancovid19, the bnpb-Indonesia account (35.24\%), and the Ministry of Health account (20.68\%) were the two Twitter accounts that used the hashtag the most during March. The \#lawancovid19 narrative on Twitter built by the government is a form of information and education communication (KIE) regarding the COVID-19 pandemic as part of preventive efforts to prevent the spread of an increasingly widespread pandemic outbreak. Thus, the use of Twitter as one of the development products of social media can be utilized by the government and the public to increase effectiveness and efficiency in disseminating disaster information. The development of disaster resilience is an effort to prepare for disasters by utilizing the potential of social media. The use of Twitter as a product of the development of social media can be utilized by the government and the public to increase effectiveness and efficiency in disseminating disaster information.

\section{ACKNOWLEDGMENTS}

The research authors would like thank to Department of Government Affairs and Administration, Post Graduated Program, University of Muhammadiyah Yogyakarta.

\section{REFERENCES}

Adnan Shereen, M., Khan, S., Kazmi, A., Bashir, N., \& Siddique, R. (2020). Covid-19 Infection: Origin, Transmission, And Characteristics Of Human Coronaviruses. Journal of Advanced Research. Https://Doi.Org/Https://Doi.Org/10.1016/J.Jare.2020.0 3.005

Amalia, YN, \& Sari, MMK (2018). Strategy of the Regional Disaster Management Agency (Bpbd) in Building Community Participation in Responding to Flood Disasters in Gresik Regency. The Study of Citizenship Morals, 6(2), 671-685.

Ariyanto, D. (2018). Institutional Coordination in Improving the Effectiveness of Regional Disaster Management Agency. Journal Of Management Review, 2(1), 161172.

Arshad Ali, S., Baloch, M., Ahmed, N., Arshad Ali, A., \& Iqbal, A. (2020). The Outbreak Of Coronavirus Disease 2019 (Covid-19) - An Emerging Global Health Threat. Journal Of Infection And Public Health, Xxx, 1-3. 
Https://Doi.Org/Https://Doi.Org/10.1016/J.Jiph.2020.0 2.033

Auliya, AP (2020). The Struggle of the People of the Country's Descending In The Face Of The Covid-19 Outbreak. Ssrn,

5. Https://Doi.Org/Http://Dx.Doi.Org/10.2139/Ssrn.3576 351

Bandur, A. (2019). Qualitative Research, Scientific MultiDisciplinary Study With Nvivo 12 Plus (Pert Edition). Jakarta: Media Discourse Partners.

Barata, GK, Lestari, P., \& Hendariningrum, R. (2018). Communication Model for Mount Merapi Disaster Management Through Plewengan Application. Journal of Communication Spectrum, 7(2), 31-45.

Fahriyani, S., Harmaningsih, D., \& Yunarti, S. (2020). The Use of Twitter Social Media for Disaster Mitigation in Indonesia. Journal of Ikra-Ith Humanities, 4(2), 56-65.

Faradilla, M. (2018). Role Of Pharmacist In Disaster Management. Pharmaceutical Sciences And Research, 5(1), 14-18.

Farida, A. (2019). Literature Study About Technological Developments And Increasing Tax Compliance: Is It Directly Comparable? Monetary - Journal of Accounting and Finance, 6(2), 135-140. Https://Doi.Org/10.31294/Moneter.V6i2.6183

Farizi, I., Ismail, N., \& Aulia, TB (2016). Preparedness Analysis Uptd Health Crisis Management Center ( P2kk ) Aceh Health Office in Facing Earthquake Disasters. Journal of Disaster Science (IF), 3(2), 85-93.

Handayani, VW, Soelistiono, S., \& Sylvaranto, T. (2018). The Effect of the Volcano Disaster Module on Improving Preparedness for Volcanic Disasters Through Facebook Case Study: Elementary School Teacher Fb Users in Sumber Wringin District, Bondowoso Regency. Scientific Journal of Business Administration and Innovation, 2(2), 236-263.

Juneza, RRD, \& Puworini, D. (2016). Responses of Persons with Disabilities to Crisis Communication Bpbd (Regional Disaster Management Agency) and Klaten Sar Team 2016. 10(1), 80-96.

Lai, CC, Shih, TP, Ko, WC, Tang, HJ, \& Hsueh, PR (2020). Severe Acute Respiratory Syndrome Coronavirus 2 (Sars-Cov-2) And Coronavirus Disease-2019 (Covid19): The Epidemic And The Challenges. International Journal Of Antimicrobial Agents, 55(3), 1-8. Https://Doi.Org/10.1016/J.Ijantimicag.2020.105924

Ling, L., Joynt, GM, Lipman, J., Constantin, JM, \& JoannesBoyau, O. (2020). Covid-19: A Critical Care Perspective Informed By Lessons Learned From Other Viral Epidemics. Anaesthesia Critical Care And Pain Medicine, $\quad \mathrm{Xxx}(4), \quad 2-5$. Https://Doi.Org/10.1016/J.Accpm.2020.02.002

Lupia, T., Scabini, S., Pinna, SM, Di Perri, G., De Rosa, FG, \& Corcione, S. (2020). 2019-Novel Coronavirus Outbreak: A New Challenge. Journal Of Global Antimicrobial Resistance, 21, 22-27. Https://Doi.Org/10.1016/J.Jgar.2020.02.021

Mahaswari, M. (2012). Jalin Merapi: Use of New Media and Social Movements for Disaster Management.
Indonesian Journal of Communication, I(2), 68-76.

Maizunati, NA (2018). Implementation of Open Sectoral Data in Supporting Smart Governance in Magelang City. Journal Of Public Administration And Local Governance, $2(2), \quad 31$. Https://Doi.Org/10.31002/Jpalg.V2i2.1082

Masdalina Pane, Isturini, IA, \& Wahidin, M. (2018). Management Of Health Crisis In Indonesia, 2016. Media Litbangkes, 28(3), 147-156. Https://Doi.Org/Https://Doi.Org/10.22435/Mpk.V28i3.1 15

Moningka, RR, Setyohadi, DB, Khaerunnisa, \& Pranowo. (2018). Identification of Basic Needs in Temporary Evacuation Sites Post-Eruption of Merapi with Sentiment Analysis and Support Vector Machine. Telematics, 15(01), 77-86.

Nashihuddin, W., \& Suryono, F. (2018). An Overview of Librarians' Readiness in Facing Professional Disruption in the Library 4.0 Era: A Literature Review. Khizanah Al-Hikmah: Journal of Library, Information, and Archival Sciences, 6(2), 86. Https://Doi.Org/10.24252/Kah.V6i2a1

Nee, RC, \& Fusco, J. (2015). Tweets During Crisis Follow One-Way Communication. Newspaper Research Journal, 36(2), 197-211. Https://Doi.Org/Http://Doi.Org/10.1177/0739532915587 295

Nurhadi, ZF (2017). Adolescent Social Communication Model Through Twitter Media. Journal of Aspikom, 3(3), 539549. Https://Doi.Org/10.24329/Aspikom.V3i3.154

War-Angin, LLK, \& Zainal, M. (2018). Political Participation of Beginner Voters in the Frame of Social Networks on Social Media. Journal of Aspikom, 3(4), 737-754. Https://Doi.Org/10.24329/Aspikom.V3i4.210

Rusdan. (2019). Realizing a Connected Government Bureaucracy as a Public Servant. Socialite Journal of Administrative Sciences, 13(1), 15-27.

Rustandi. (2019). Performance of Human Resource Management in the Era of Disruption. Policy: Journal of Administrative Sciences, 10(2), 67-73.

Silmi, NR, Nur, T., \& Purwanti, D. (2019). Implementation of Regional Disaster Management Policy in Sukabumi City. Joppas: Journal Of Public Policy And Administration Silampar, 1(1), 30-40.

Subekti, P., Hafiar, H., \& Bakti, I. (2020). Use of Instagram by Regional Disaster Management Agency to Optimize Pangandaran Destination Branding. Journal of the Public Relations Profession, 4(2), 174-192. Retrieved From Http://Jurnal.Unpad.Ac.Id/Profesi-Humas

Yulfa, A., Aditya, T., \& Sutanta, H. (2019). Spatial Data Infrastructure Enrichment Using Crowdsourced Data For Emergency Response. Globe Scientific Magazine, 21(2), 95-104. Retrieved From Http://Dx.Doi.Org/1024895/Mig.2019.21-2.936

Yuliana, I. (2019). Adoption of Social Network Analysis (SNA) in an Effort to Build Disaster Resilience in the Community. Journal of Informatics and Computer Science (Jiko, 2(2), 49-54. Https://Doi.Org/Http://Dx.Doi.Org/10.33387/Jiko 